\title{
Fontes educativas da agroecologia no Assentamento Margarida Alves: a transição do movimeno na Amazônia
}

\author{
José Leonidas Couman ${ }^{1}$ \\ Diógenes Valdanha Neto ${ }^{2}$
}

\begin{abstract}
RESUmo: A ocupação da Amazônia segue subjugada ao avanço desenfreado do grande capital, que se revela socio e ambientalmente insustentável. Frente a isso, o Movimento dos Trabalhadores Rurais Sem Terra (MST) tem lutado para a construção de novos sujeitos e dinâmicas no mundo rural que tenham a agroecologia como orientadora de suas práticas. Este estudo teve o objetivo de compreender quais foram as principais fontes educativas que inspiraram a produção agroecológica inicial do Assentamento Margarida Alves, localizado no município de Nova União - Rondônia, e também descrever elementos do processo da mudança do modelo de produção convencional para o agroecológico do assentamento, e apresentar avanços e limites conjunturais em seu processo de transição na produção agroecológica. A metodologia foi qualitativa, pautada na realização de entrevistas com 10 moradores do assentamento, e observação direta com registro em diário de campo. Os dados revelam que o MST foi o principal ator a introduzir as ideias da agroecologia no contexto local, e que essa perspectiva representa dialeticamente algo antigo e novo para os assentados, que reconhecem seu potencial de transformação de sua realidade e apontam caminhos para seu fortalecimento.
\end{abstract}

Palavras-Chave: Educação do Campo; Agroecologia; Reforma Agrária; Meio Ambiente; Amazônia.

\section{Educational sources of agroecology in the Margarida Alves Settlement: the transition of MOVEMENT IN THE AMAZON}

ABSTRACT: The occupation of the Amazon region is still subjugated to the unbridled advance of capital, which proves to be socially and environmentally unsustainable. In this sense, the Landless Workers' Movement (MST) has been fighting for the construction of new subjects and dynamics in the rural world that have agroecology as a guide to their practices. This study aimed to understand what were the main educational sources that inspired the initial agroecological production of the Margarida Alves Settlement, located in Nova União Rondônia, and also to describe elements of the process of change from the traditional to the agroecological production model of the settlement and present conjunctural advances and limits in its transition process to agroecological production. The methodology was qualitative, based on interviews with 10 residents of the settlement, and direct observation recorded in a field diary. The data reveal that the MST was the main actor introducing the ideas of agroecology in the local context, and that this perspective dialectically represents something old and new for the settlers, who recognize its potential for transformation of their reality and point ways for its strengthening.

\footnotetext{
${ }^{1}$ Assentado da Reforma Agrária e militante do MST. Licenciado em Educação do Campo (UFTM). Membro do Laboratório de Meio Ambiente, Ciência e Educação (LAMACE-UFTM).E-mail: jlcouman@outlook.com

${ }^{2}$ Biólogo, mestre em Educação Escolar e doutor em Educação. Professor da Universidade Federal do Triângulo Mineiro (UFTM), onde coordena o Laboratório de Meio Ambiente, Ciência e Educação (LAMACE).E-mail: diogenesvn@gmail.com
} 
KEYwORDS: Rural Education; Agroecology; Agrarian Reform; Environment; Amazon.

\section{INTRODUÇão}

O Movimento do Trabalhadores Rurais Sem Terra (MST) tem ocupado lugar de referência na criação e fortalecimento de propostas de agricultura alternativas ao modelo do agronegócio, que tem o objetivo maior de produzir mercadorias e acumular capital (ROCHA; NOBRE, 2017). A principal perspectiva agregadora dessas alternativas é a Agroecologia, que combina conhecimentos produzidos pela ciência laboratorial, pela ciência popular, e também no movimento das lutas sociais.

Apesar do pluralismo epistemológico e de práticas que compõe a perspectiva da agroecologia, nas experiências junto aos movimentos sociais que têm fomentado concretamente a construção dessas iniciativas no Brasil, a agroecologia tem sido considerada um "modelo". No sentido de ser uma referência de contraposição ecológica e social à agricultura convencional, derivada da Revolução Verde, que gera dependência do produtor com relação a insumos e sementes, prendendo-o ao sistema econômico de forma subjugada. Ou seja, apesar de não se configurar como um modelo uno, a agroecologia tem figurado como a unidade na diversidade das práticas que fomentam a emancipação dos agricultores brasileiros (CUENIN et al., 2019; MACHADO; MACHADO FILHO, 2014).

Tão importante quanto a transformação dos modos de produção camponeses, a educação também é uma das principais bandeiras do MST, fomentando a criação de escolas diferenciadas (RIBEIRO; PARAÍSO, 2015), e também de cursos universitários ímpares para a formação de professores (SOUZA; VALDANHA NETO, 2018). Tudo isso em uma chave teórico-prática forjada nas lutas sociais latino-americanas, e inspiradas amplamente na obre de Paulo Freire (CALDART, 2012; WHITAKER, 2008).

Neste cenário, localizar a Amazônia e captar algumas das especificidades de seus processos de produção do campesinato na contemporaneidade é encarar não somente aspectos sociais das questões envolvendo a Reforma Agrária, mas também sua essência socioambiental. Os modelos de desenvolvimento que grassam sobre o bioma são, ainda, majoritariamente reflexos do avanço desregulado do grande capital - sobretudo por meio da construção de grandes rodovias e usinas hidrelétricas (ARBEX JR, 2005). Cenário sobre o qual a luta pela reforma agrária tem papel indispensável para tensionar processos de garantia de dignidade para os trabalhadores do campo (WHITAKER, 2011; LOUREIRO, 2009).

Assim, este estudo buscou compreender quais foram as principais fontes 
educativas que inspiraram a produção agroecológica inicial do Assentamento Margarida Alves, localizado no município de Nova União - Rondônia. Teve-se como objetivos específicos: descrever elementos do processo da mudança do modelo de produção convencional, derivado da Revolução Verde, para o agroecológico no assentamento, e apresentar avanços e limites conjunturais em seu processo de transição na produção agroecológica.

\section{O Contexto Do Caso}

Em 10 de outubro 1997, o assentamento Margarida Alves foi legalmente instituído, através do processo 1365/96 RO, em que o INCRA desapropriou mediante negociação de compra e venda as Fazendas FIRASA e ANINGA, numa área territorial de quase 12.000 hectares, assentando no local um total de 258 famílias. Perante as necessidades econômicas os camponeses locais variaram sua produção visando a sustentabilidade econômica para seus familiares, sem atingir uma identidade produtiva bem definida (ARAÚJO, 2015).

O assentamento está localizado na região central do Estado de Rondônia e é conhecido na região pela sua produção de leite - com ampla maioria dos produtores considerados como pequenos e médios produtores. O município de Nova União tem aproximadamente 7000 habitantes, e cerca de um terço dessa população são famílias assentadas pelo programa de Reforma Agrária (IBGE, 2010). A princípio, uma das grandes esperanças desses moradores foi a agricultura camponesa, aderiram a plantio de café (Coffea arabica) como uma fonte renda anual.

No entanto, o cultivo cafeeiro não atingiu as expectativas com relação à geração de renda devido à dificuldade de escoamento da produção. Atualmente, o que predomina é criação de gado, que de uma forma geral proporciona duas fontes de renda: o leite e a carne. O leite, mesmo a baixo preço, acaba sendo a saída para esses agricultores aumentarem sua renda mensal.

A partir de maio de 2004, os produtores, sentindo a necessidade de organizar a produção, decidiram constituir uma cooperativa e criar grupos para trabalhar a partir da perspectiva sistema agroecológica, que poderiam dar um suporte à produção de leite, e também na agricultura familiar.

A luta pela reforma agrária no Brasil é antiga e enfrenta um modelo de ocupação territorial imposto desde o processo de colonização: o latifúndio monocultural. Os camponeses expropriados da terra defendem a necessidade de um novo modelo de sociedade para o Brasil, pautado na produção familiar e distribuição de terras mais equitativa (OLIVEIRA, 2007).

Oliveira (2007) defende a compreensão de que o capitalismo no mundo rural 
se desenvolve de um modo contraditório e combinado, permitindo que a classe camponesa siga a existir mesmo em condições de exploração e expropriação pelo capital. Ou seja, à medida que esse desenvolvimento avança, reproduz relações especifica capitalista, produz também relações com os camponeses de produção.

A agroecologia representa uma forma de abordar agricultura que incorpora cuidados especiais relativos ao ambiente, aos problemas sociais e à sustentabilidade ecológica dos sistemas de produção. No entanto, como destaca Altieri (2010, p. 29)

A realização do potencial e a difusão das inovações agroecológicas depende de vários fatores e grandes mudanças nas políticas agrárias, nas instituições e nos métodos de investigação e extensão. As estratégias agroecológicas propostas têm que apontar deliberadamente aos pobres, não somente para aumentar a produção e conservar os recursos naturais, mas também para gerar emprego e oferecer oportunidades de acesso aos mercados locais.

Assim, compreender os meandros dos processos educativos e de transição para o modelo agroecológico, especialmente no bioma amazônico, poderá auxiliar no fortalecimento de propostas de ação e políticas públicas visando ao desenvolvimento autônomo desses sujeitos. Uma vez que, mesmo em tempos de recessão econômica e de um Estado que tem paulatinamente se eximido de suas funções na distribuição de renda, a agroecologia pode iluminar caminhos mais emancipados de desenvolvimento local.

\section{Metodologia}

A abordagem metodológica desta investigação se localiza nos métodos qualitativos da pesquisa em Educação. Nesse contexto, o processo descritivo visa à identificação, registro e análise das características, fatores ou variáveis que se relacionam com o fenômeno ou processo. De acordo com Stake (2011), estudos de natureza qualitativa tratam de oferecer fonte de informações que permitem entender e compreender valores sociais e culturais da comunidade.

Os instrumentos utilizados para a coleta de dados foram a entrevista semiestruturada e a observação direta. Os registros foram realizados por gravador de áudio, com posterior transcrição integral das entrevistas, e por caderno de campo no caso das observações.

Uma vez que o primeiro autor deste estudo é também assentado no local, e envolvido com as questões internas da comunidade, foi necessário um exercício de distanciamento epistemológico. Ao mesmo tempo em que essa situação não foi negada, mas sim reconhecida como potência para uma análise de dados mais 
complexa e próxima da realidade.

A pesquisa de campo foi realizada entre os meses de novembro e dezembro de 2017, com 10 agricultores do assentamento Margarida Alves. Os participantes da pesquisa (entrevistados) estão apresentados no Quadro 1. O principal critério de escolha dos sujeitos foi o vínculo como movimento social que responde pelo coletivo do assentamento, o MST.

Quadro 1 - Participantes da pesquisa.

\begin{tabular}{|c|c|c|c|c|}
\hline Participantes & Naturalidade & Idade & Sexo & $\begin{array}{c}\text { Tempo de assentamen- } \\
\text { to: }\end{array}$ \\
\hline JR & Minas Gerais & 60 anos & Masculino & Desde 1996 \\
\hline CJ & Paraná & 47 anos & Masculino & Desde 1996 \\
\hline JÁ & Paraná & 45 anos & Masculino & Desde 1996 \\
\hline ED & São Paulo & 38 anos & Masculino & Desde 2003 \\
\hline NA & Minas Gerais & 50 anos & Masculino & Desde 1996 \\
\hline AM & Rio Grande do & 55 anos & Feminino & Desde 1996 \\
\hline WA & Paraná & 38 anos & Masculino & Desde 1998 \\
\hline TA & Piauí & 35 anos & Masculino & Desde 2006 \\
\hline VA & Pernambuco & 47 anos & Masculino & Desde 1997 \\
\hline LE & Rondônia & 27 anos & Masculino & Desde 1998 \\
\hline
\end{tabular}

Fonte: elaborado pelos autores.

Os nomes reais dos participantes foram suprimidos, evitando assim qualquer exposição que possivelmente gerasse algum desconforto, conforme o acordo feito com esses sujeitos. Foram utilizadas siglas para cada entrevistado. A transcrição das falas adotou os procedimentos defendidos por Whitaker (2005), em uma postura ética de combate a preconceitos com sujeitos rurais. A seguir serão apresentados os principais resultados obtidos e análises em diálogo com o referencial teórico utilizado.

\section{RESULTADOS E DISCUSSÃo}

As questões das entrevistas foram abertas e objetivavam compreender o conhecimento dos camponeses a respeito do tema "agroecologia". Todos os participantes responderam que conhecem ou já ouviram falar sobre agroecologia, disseram tratar-se de uma agricultura preocupada com o meio ambiente e acreditam ser uma agricultura sem uso de agrotóxicos e saudável. 


\section{Por MeIO DE ONDE?}

Mesmo se tratando de uma questão aberta, as respostas dos primeiros entrevistados foram bastante homogêneas, disseram que o conhecimento obtido deu se através de Associação, Cooperativa, Emater, Pastoral da saúde, MST. A partir destas respostas foi possível identificar (Figura 01) que dos dados obtidos: $10 \%$ o conhecimento deu se através de associações, $10 \%$ de cooperativas, $10 \%$ da Emater, $20 \%$ pastoral da saúde e 50\% MST.

Figura 01 - Fontes primárias para o conhecimento agroecológico do assentamento.

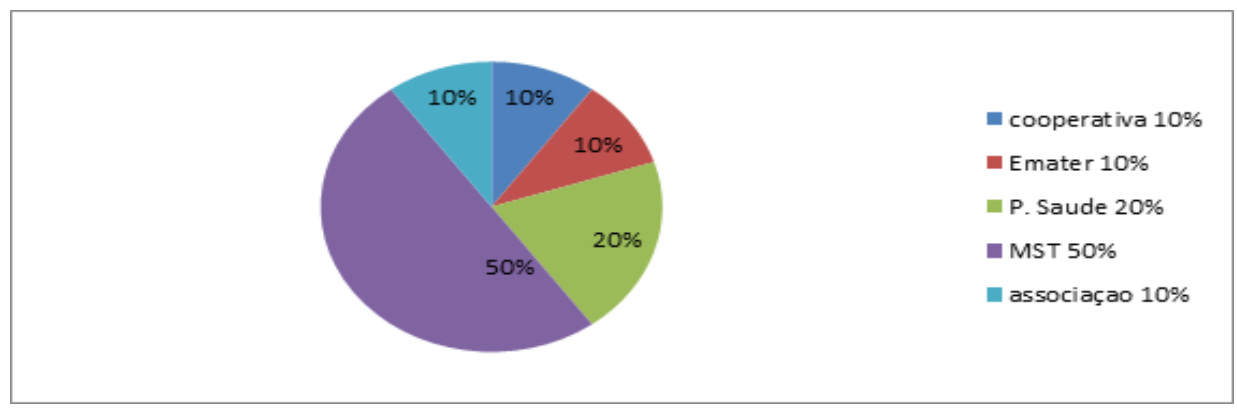

Fonte: elaborado pelos autores.

Esses dados reforçam a assertiva de que o MST não é um movimento que luta apenas pelo direito de acesso a terra, ou seja, pela Reforma Agrária. Luta por uma transformação da sociedade e seu modo de produção agrário e de relações entre seres humanos, uma vez que a agroecologia não se resume apenas à produção, mas também envolve premissas de condições de trabalho dignas e emancipadas da exploração do grande capital. Ademais, os dois assentados mais velhos afirmaram ter aprendido inicialmente sobre agroecologia com a Pastoral da Saúde, provavelmente em tempos anteriores à criação do MST.

Ao ser questionado sobre por meio de onde tinha ouvido falar sobre Agroecologia, AM destaca que esse é um movimento já dado na relação tradicional com o campo, e também de uma maneira organizada no MST. Ou seja, para quem é camponês a Agroecologia representa algo antigo e novo ao mesmo tempo: antigo porque é a prática que seus antepassados realizavam de produção, sobretudo para consumo; novo, porque agora é utilizado, em um novo estágio de amadurecimento e tecnificação, como bandeira de enfrentamento ao modelo dominante e explorador.

AM: Ouvi falar diretamente assim de agroecologia foi quando a gente entrou é... dentro das organização que a gente começou a perceber. Mas assim é.... 
na minha criação já desde, desde a infância, a gente já acostumava assim de não devastar, proteger as coisas, né?

[…

Só que pra mim já era uma coisa natural mais diferente do que, como vou dizer... Agroecologia. Agroecologia agora pra mim está mais claro.

AM relata as estratégias de plantio de sua família, e cita a rotação de cultivos como algo que ela liga à Agroecologia. Essa técnica é sim valorizada e, por vezes, utilizada na agroecologia, mas existe registros de sua utilização desde o feudalismo. Ou seja, há milhares de anos a humanidade já sabe da importância do pousio para a recuperação do solo, mas o agronegócio insiste em ignorar e lutar contra essa imposição da natureza. A que custo?

Pesquisador: Sim. Então esses cuidados que a senhora tinha de antes era relacionado a família mesmo, era tradição da família?

AM: Familia, era desde minha avó, por exemplo. A semente a gente guardava, a semente crioula guardava, né? Porque a semente...e também nós mudava de chão de um lugar pra outro, sempre a gente trocava de lugar, por exemplo. Eu aprendi na agroecologia, não é agroecologia na verdade, a gente falava assim, "é proteger esse pedaço aqui" por exemplo, eu vou proteger esse pedaço de terra aqui de um ano, de um ano pra cá depois eu vou preparar ele, pra mim plantar daqui uns dois anos, porque ai ela tinha descansado, ela descansava, parece que voltava a natureza de novo. E ai não plantava a mesma semente aqui sempre a gente trocava o quintal de semente diferente, porque eu aprendi assim, então pra mim já era naquele tempo. Porque não é agroecologia, já era uma forma diferente assim de proteção. Agora a palavra Agroecologia aprendi já de uma outra forma, agora já sei o que que é na verdade.

Importante também o destaque que CJ traz sobre os ensinamentos do MST acerca da produção de alimentos (vida). Deve ser feita com respeito a todos os seres, e não visando ao lucro, como impõe o agronegócio

CJ: [Aprendi sobre a Agroecologia no MST] No setor de produção e saúde. Que o movimento tem esse negócio, ou a gente acerta com todo mundo, ou erra com todo mundo. Mas aí essa questão nossa é um vício que nós tem esse modelo de agricultura. Mas desde o início sempre foi falado pra gente [pelo MST] que o modelo nosso de agricultura nosso seria esse. Esse ai sem produzir...na verdade com respeito com tudo, né? Com os seres viventes, 
até aqueles que a gente não está vendo.

\section{O Que pensa sobre a Agroecologia?}

Acerca desta questão, as respostas revelam que, muitas vezes mesmo sem utilizar dos jargões e palavras-chave acadêmicas, os camponeses compreendem princípios e premissas da Agroecologia e os comunicam de modo mais criativo. Como a fala de CJ, que sem fazer explicitamente, relaciona a Agroecologia com o princípio da Sustentabilidade (produzir sem prejudicar a capacidade de produção futura).

CJ: A Agroecologia, na verdade, ela é mais uma questão de a gente querer não... tipo assim, ou nós faz esse processo ou todo mundo vai sofrer. Porque, tipo assim, diante de todas essas agravações que nós está tendo de aquecimento global, e toda a destruição, né? Se a gente não faz essa mudança, o que é que vai ficar para nossa juventude, nossos netos?

CJ continua, destacando sua compreensão de que a produção Agroecológica é um serviço que os camponeses fazem para a humanidade, para o bem comum. É imperativo, e deve ser seguido por todos os produtores rurais, evitando, assim, consequências catastróficas (desrespeitosas para com a humanidade) na natureza.

CJ: Porque, a água vai embora porque nós destruiu ela, então nós ... ou nós assume esse papel. Ou não adianta nós ficar chorando não, pela salvação. Porque precisa ser feito.

Chegou num limite que não tem mais... até agora nós viemos assim, é... assim... inventando desculpas. E agora não tem mais como inventar desculpas, né? "Ah, eu vou fazer". Mas agora não! Agora tem que fazer mesmo! Não tem outra saída. Ou nós fazemos essas mudança, esse serviço nosso de abandonar o veneno e fazer esse modelo respeitando a natureza, ou, caso contrário, a natureza vai desrespeitar nós também.

Frente à força e pressão hegemônica do agronegócio, que se apresenta constantemente (e ideologicamente) como a única possibilidade viável de produção no campo, TA destaca que para enfrentar essa hegemonia tão grande é preciso certo componente de crença.

TA: Rapaz, esse negócio é o seguinte.... Eu, eu acho que a gente tem que partir do princípio que funciona e que acredita. A partir do momento que eu acredito que funciona, eu vou me desafiar a plantar, a produzir com ela, né? É.... são experiências, tem hora que você acerta, tem hora que você não 
acerta, tem hora que você planta, faz uma plantação e um não combina com o outro, um sufoca o outro. Então você acaba não desenvolvendo, adquirindo a produção que você precisa, queria, imaginava, mas é uma produção que dá certo, é um modelo de produção que a pequena propriedade que... que é o meu caso, funciona. E que assim, espero que outras pessoas, de mais áreas de assentamento, se desafiem porque, primeiro de tudo, é um desafio, né?

A fala de TA não altera o fato de que diversos estudos e experiências corroboram a total viabilidade da produção por meio de sistemas agroecológicos (MACHADO; MACHADO FILHO, 2014). Todavia, para o camponês que está na lida diária com a natureza e perante o modelo hegemônico, a fé e coragem para lutar por uma sociedade melhor devem exercer forças de movimento para a transformação.

\section{DESENVOLVE PRÁTICAS AGROECOLÓGICAS NO SEU LOTE?}

De uma maneira geral, os entrevistados desenvolvem algumas práticas que podem ser consideradas agroecológicas, ou de agricultura orgânica. A utilização de homeopatia para o tratamento do gado é também uma constante, algo que se aproxima dos princípios agroecológicos. No entanto, reforçam o desafio da produção agroecológica em meio a um contexto de degradação humana, social e ambiental que os pressiona a ceder ao modelo hegemônico de produção.

LE, ao ser questionado sobre a prática agroecológica em seu lote, conecta-a à preservação de nascentes. Ou seja, há uma preocupação com a conservação ambiental que não é típica do modelo do agronegócio. Ademais, ficam as dificuldades conjunturais de se produzir em larga escala de modo agroecológico:

LE: [...] Eu planto milho, plantei já o milho e arroz, o milho foi orgânico, foi através da, da enxada, não viu um grama de veneno. É... protejo, tem uma área de nascente protegida, é... tem duas nascentes protegidas, uma que eu estou recuperando agora. E os rios, as beiras dos rios eu tenho consciência que tem que deixar a... a mata nativa tal pra preservar, né? Diante disso eu não produzo no sistema agroecológico, mas eu tenho consciência do que é bom e do que é ruim, então através de pequenas atitudes a gente está praticando a agroecologia.

Um dos participantes, VA, comunica que compreende a Agroecologia como uma "tarefa socioeconômica" de toda a humanidade, uma necessidade. E destaca dificuldades, mas também movimentos para a transição agroecológica.

VA: A gente na verdade aqui está produzindo até pouco, né? Essa é a verdade. 
Mas aqui nós temos já aproximadamente uns 13 anos que nós não usamos mais venenos aqui nesse lote, nessa terra nossa, né? Não usa veneno. E eu entendo assim que a natureza ela, ela já vem completa, né? Ela não veio incompleta, né? Então tudo que se joga que se faz mal, não faz bem nem pra natureza nem pra, para os seres vivos que estão em cima dessa, dessa terra que vive aqui na Terra, né? Então eu acredito que: na verdade talvez tem uma dificuldade da gente não conseguir incorporar isso na vida cotidiana no sentido de encontrar um jeito de produzir mais, né? Mas assim eu, por exemplo, na minha visão, na minha compreensão, a agroecologia, defender a natureza, deveria ser um, uma tarefa socioeconômica de toda a humanidade, né?

\section{Por Que utiliza a Agroecologia? Quais suas vantagens?}

As justificativas para a utilização da Agroecologia foram todas apresentadas associadas a posicionamentos éticos perante a vida e a humanidade. Nenhum dos entrevistados ligou a utilização da Agroecologia exclusivamente à questão da produtividade e renda. ED destaca questões de saúde que são incluídas com a não utilização de agrotóxicos, e também a economia (e emancipação) possível ao se deslocar da rede de dependência criada pelo agronegócio.

ED: Na Agroecologia você usando a prática agroecológica ou a natural, você evita de intoxicação de... com agrotóxico, né? Ela não te dá esse problema de intoxicação, nem sua e nem dos animais, nem das plantas. E também o... o valor, né? O valor é menos, o valor de você mexer com Agroecologia é um valor menor, né? De que você comprar nas agropecuárias os remédios [...].

TA apresenta as impressões do ecossistema como um todo, a utilização de agrotóxicos rompe com toda uma rede de relações entre diferentes espécies. Também, destaca a questão da produção de alimentos. A produção agroecológica serve à produção de comida (que visam à saúde), e não de mercadorias (que visam ao lucro).

TA: E olha só, olha o milho do vizinho, você pode passar ali que não tem periquito. Homeopatia de periquito pra o controle do periquito não .... Você pode ir ali, você pode tirar... você pode andar ali, você não vai ver periquito, você vai ver macaco mas periquito você não vai ver. E... porque faz o processo da homeopatia, né? A lei da semelhança e ai ele.... Ele espanta. Mas só assim, não sei se vai te ajudar, como o.... como referência na pergunta anterior e a respeito da produção agroecológica, nesses espaços que a gente 
vai, pra feira, ai seria o seguinte... quando a pessoa questionar "Ai essa produção é sem veneno? Eu posso confiar?” Você pode confiar, porque... eu não vendo a sobra, eu vendo o excedente eu sempre planto um pouco a mais, pode ver o tanto de coisinha a mais que tem.

Como já foi apresentado, a Agroecologia se pauta nas dimensões econômicas, sociais e ambientais da sociedade para operar seus princípios e funcionamentos. CJ destaca essas esferas ao citar as vantagens de se trabalhar com a Agroecologia, e na questão econômica já está implicada em sua fala a preocupação com a saúde: é preciso ter uma produção dentro do mercado, mas de alimentos, e não apenas mercadorias.

CJ: Tem três coisas, né? Uma coisa é a questão ambiental, de você estar contribuindo, né? Porque quando você não está batendo veneno no gado, você vê no meio do pasto aquelas garça, você vê gavião, tudo se alimentando. Se tivesse veneno eles não vinha aqui, morria tudo. Então tem a questão ambiental, de estar contribuindo. A questão das finanças, que está sempre contribuindo porque não está precisando de gastar. E a outra é a questão do produto mesmo, que você está se alimentando e você sabe que não tem esse lance, né? No leite, no tomate.

Ao ser questionado sobre as vantagens da Agroecologia, VA enfatiza sua possibilidade real de implantação e produção em larga escala. Destaca que, apesar de ser contra hegemônica, a Agroecologia é alternativa viável frente ao que se apresenta como único modelo, o agronegócio. Destaca experiências empíricas de constatação dessas assertivas, e o poder do observável frente ao discurso.

VA: Eu só quero dizer que em termos de produção é possível produzir IGUAL, porque tem muito daquela histórica que a, a agroecologia produz um produto de segunda, terceira qualidade.... Não é verdade! Eu já vi em lugares que não usa veneno que, que o.... as plantas saem até mais bonito, né? Então assim, eu acredito que é um vício, né? O ser humano vai sendo viciado, adomado a determinadas lógicas, né? De tanto que você escuta pros quatros cantos.... "Ah, não tem como mais plantar sem veneno".... Isso é uma bobagem, isso é um grande equívoco que a humanidade comete, né? Então eu acredito assim: claro que você talvez tenha roças menores na agroecologia, e quando você usa química ou desgraça a vida da natureza, você pode até produzir quantidades maiores, né? Mas em termos de qualidade eu acredito que a agroecologia produz de igual pra.... De igual até pra melhor, né? No caso, né? Então assim eu só acho que é um vício que vai implantando na cabeça do ser humano e a gente vai, indo para 
aquele lado e parece que não tem volta, né? Mas eu produzi aqui olha, couve aqui, rúcula, mas coisas maravilhosas assim sem nenhuma gota de.... Eu vi também no 14 de agosto o alface deles, gente do céu, cada pé de alface que você olhava assim, ai não tem como dizer que não é possivel produzir de primeira qualidade, né?

\section{NEM TUDO SÃo FLORES...FRUTOS E SEMENTES: O CONTRADITÓRIO}

Dada sua natureza de vertente contra hegemônica, já é claro desde o ponto de partida de sua compreensão que não há apenas vantagens, ou pontos positivos na implantação da Agroecologia como modelo produtivo. No cotidiano camponês, muitas são as dificuldades impostas pelo modelo econômico vigente que tornam a transição agroecológica difícil e, muitas vezes, inviável em alguns contextos específicos.

Revelou-se importante destacar algumas das falas que revelam esses desafios, que aproximam de uma maior compreensão do complexo cenário da vida e produção camponesa familiar em um país de histórico tão opressor no campo como o Brasil. AN destaca que o modelo agroecológico muitas vezes requer mais tempo de trabalho e tem um tempo de produção mais lento, o que pode desanimar alguns camponeses a adotá-lo.
AN: Porque a convencional é fácil, né? Que pode ser dificil pro futuro, o agroecológico é mais difícil porque você.... por exemplo a gente vai forma um pasto juntamente com a madeira.
Você vai ter que bater uma cerca, se não o gado vai quebra. Você tem uma cerca, você tem que ter um arame, o custo não é baixo, mas devagarinho vai fazendo, né?

WA também explicita que o tempo "natural" da produção, que é mais próximo do agroecológico, é mais lento do que o tempo de produção com insumos químicos e utilização de agrotóxicos como feito pelo agronegócio. Essa resposta mais rápida acaba cooptando a produção camponesa para o modelo hegemônico, em uma tentativa de conseguir melhores condições de comercialização de seus produtos e resistir um pouco mais fortemente às opressões e degradações que o sistema econômico impõe aos trabalhadores rurais brasileiros. Como representa a fala: " $E$ porque as coisas... o natural, ele é mais lento e às vezes nem todo mundo, às vezes mexe porque às vezes acha que não tem essa paciência, né?".

Todavia, é preciso lembrar que a Agroecologia utiliza de técnicas e sistemas sofisticados do ponto de vista da ciência ecológica para potencializar uma produção 
que se assemelhe ecologicamente com o funcionamento dos ecossistemas locais, mas ao mesmo tempo tenha uma potência de produção muito mais acelerada do que a da natureza. Esse é o princípio que guia os sistemas agroflorestais, por exemplo, consagrada ferramenta da Agroecologia. No entanto, é reconhecido que a implantação efetiva de um sistema agroflorestal requer maior tempo de trabalho e dedicação do que o de uma cultura simples.

Nesse sentido, JA destaca que a Agroecologia exige da humanidade "um tempo melhor". Não "maior", como a pressão do mercado faz crer. Mas sim de melhor se relacionar com o meio ambiente e com os seres humanos que nele trabalham.

JA: Então, se a gente quiser pensar no, no mundo melhor, em um mundo que ainda consiga ter uma dignidade, uma qualidade de vida, dai eu diria pra todo mundo que a forma como nós faz está totalmente errado, né? Esse campo convencional de... de destruir para produzir, então logico que a minha orientação aí seria nessa linha da agroecologia mesmo, entendeu? Você trabalhar com.... trabalhar usando o que de melhor a terra pode te oferecer, não é destruir a terra pra produzir, é.... é tirar dela aquilo que ela tem de melhor pra você, né? E isso é possivel fazer, é tranquilo pra fazer. Agora, é claro que ela exige talvez assim um tempo melhor da gente, da gente observar, da gente acompanhar, da gente estar dentro ali. Que é uma observação que a própria pessoa tem que fazer né, do seu plantio, né?

\title{
Quais as PROPOSTAS/SUgestões PaRa O FORTALECIMENTO Da PERSPECTIVA AGROECOLÓGICA?
}

Os participantes da pesquisa, ao serem questionados sobre propostas para uma maior implantação da Agroecologia na agricultura camponesa, recorreram muito à importância do exemplo observável, concreto. Fica subentendido que o discurso apenas não irá sustentar toda a transição agroecológica, é preciso fatos observáveis para estimular uma maior adesão. Como destaca AN em sua fala:

\begin{abstract}
AN: A minha proposta seria o seguinte, que a gente escolhia uma área de um produtor, e a gente fazia as áreas demonstrativas... como é que funciona isso, em conjunto, a gente sempre ia unir, tirar a ideia e pôr na prática, para a gente ver como é que vai funcionar..
\end{abstract}

A participante AM enfatiza, também, a necessidade de inspirar a transição agroecológica por meio de estímulos racionais, e não apenas slogans. É preciso demonstrar para os camponeses que é viável e mais interessante para todos a produção agroecológica. 
AM: É... Se tivesse um grupo que por exemplo, se tivesse 10 pessoas, eu sempre penso isso aí, 10 pessoas, vamos produzir... 5 quer produzir tradicional e 5 quer produzir agroecológico. Para a gente convencer aqueles 5 ali, você tem que começar com aqueles 5 e primeiro conscientizar, colocar todos as....tipo eu não sou boa de matemática, né? Mas pode-se explicar sem usar muitas vezes a caneta, pra você fazer o balanço... uma comparação. Quanto você vai gastar aqui, e quanto você vai gastar? Depois aqui quanto que você vai gastar e depois, segundo passo, é convencer que essas pessoas entra na... no ecológico [...] Mas.... Mas que a gente tem proposta, teria proposta assim, vamos fazer todo mundo aceita, colocar... primeiro colocar todas as vantagens e desvantagens que tem no tradicional, e a vantagem que tem no agroecológico, pra gente convencer porquê.... E também um pouco de estudo, com alguém aí, algum acompanhamento aí, algum técnico, busca também aquilo que a gente aprendeu por exemplo, você tem os biofertilizantes que pode ajudar, começar a prática, tem que começar a prática, que só falar não dá, tem que começar.

\section{$[\ldots]$}

AM: Eu acho que tem que começar, começar fazendo e ai de repente sempre tem aqueles cinco que não vai, mas cinco vai, se os cinco irem, logo os cinco vêm.

Pesquisador: Então acho que eu entendi. Então, segundo a senhora, para tentar convencer primeiro tem que estar praticando, primeiro mostrar na prática.

AM: Tem, pegar um grupo e praticar, mostrar na verdade que está certo e compensa.

Os dados aqui apresentados reforçam as assertivas de Altieri (2010) acerca de uma centralidade prática e econômica esperada dos sistemas produtivos agroecológicos. Elementos que não devem ser combatidos na situação de economia globalizada, a fim de se exigir dos sujeitos do campo uma postura heroica irreal que pouco contribuiria para a transformação de suas realidades.

Como os participantes deste estudo demonstram, as lutas e busca de transição para um modelo agroecológico nada tem de economicismo. Tratam-se de movimentos de valorização da vida e de propostas de novos paradigmas de existência no campo e também na cidade, ao se construir uma relação diferenciada com a biodiversidade.

Neste sentido, destaca-se a relevância de compreensão dos meandros pelos quais 
os camponeses brasileiros têm apontados alternativas à realidade socioeconômica de exclusão que enfrentam. Os ensinamentos desses sujeitos se configuram como a mais forte luz e caminho de saída do cenário de trevas e destruição no qual a Amazônia se encontra. Há vida e sabedoria, é preciso que seja ouvida.

\section{CONSIDERAÇões FINAIS}

Este estudo revela o papel central do MST na formação de sujeitos críticos e com conhecimentos híbridos para uma produção agroecológica. Para além de órgãos de extensão rural, foi o movimento social o principal responsável pela tematização da agroecologia no Assentamento Margarida Alves. O que não minimiza o papel de assistência e assessoria rural dos órgãos extensionistas, mas demonstra a centralidade do movimento na colocação da perspectiva no contexto local.

Os processos de mudança do modelo de produção convencional, derivado da Revolução Verde, para o agroecológico são complexos, e seus meandros evidenciam a ambivalência da agroecologia para os camponeses: é algo antigo e novo ao mesmo tempo: antigo porque é a prática que seus antepassados realizavam de produção, sobretudo para consumo; novo, porque agora é utilizado, em um novo estágio de amadurecimento e tecnificação, como bandeira de enfrentamento ao modelo dominante e explorador.

Os limites conjunturais estão localizados no âmbito da práxis. Embora os sistemas produtivos sejam dependentes, ao menos em partes, das políticas púbicas de financiamento rural, os camponeses têm lançado mão de iniciativas inspiradoras mesmo em cenário desfavoráveis ao seu avanço. Esses dados demonstram a potência dessas iniciativas, e o sentido de o Estado investir mais nas ações de fomento à agricultura camponesa agroecológica caso se almeje uma sociedade mais justa e sustentável.

\section{REFERÊNCIAS}

ALTIERI, Miguel A. Agroecologia, agricultura camponesa e soberania alimentar. Revista NERA, v. 13, n. 16, 2010.

ARAÚJO, Marcel Eméric Bizerra de. A vida e a produção do assentamento Margarida Alves em Nova União, Rondônia. Dissertação (mestrado) em Geografia. Universidade Federal de Rondônia, Porto Velho Rondônia, 2015.

ARBEX JR, José. “Terra sem povo”, crime sem castigo: pouco ou nada sabemos de 
concreto sobre a Amazônia. In: TORRES, Maurício (Org.). Amazônia revelada: os descaminhos ao longo da BR-163. Brasília: CNPq, 2005.

CALDART, Roseli Salete. Pedagogia do movimento sem terra. $4^{a}$ edição. São Paulo: Expressão Popular, 2012.

CUENIM, Pauline Hèléne Cécile Marie et al. A transição para um sistema alimentar mais sustentável: o papel da agroecologia e suas mudanças epistemológicas. Revista Brasileira de Agroecologia, v. 14, n. 2, 2019.

IBGE. Instituto Brasileiro de Geografia e Estatística. Censo populacional. 2010. LOUREIRO, Violeta Refkalefsky. A Amazônia no século XXI: novas formas de desenvolvimento. São Paulo: Editora Empório do Livro, 2009.

MACHADO, Luiz Carlos Pinheiro; MACHADO FILHO, Luiz Carlos Pinheiro. Dialética da agroecologia. $1^{a}$ edição. São Paulo: editora Expressão Popular, 2014.

OLIVEIRA, Ariovaldo Umbelino. Modo de Produção Capitalista, Agricultura e Reforma Agrária. São Paulo: Labur Edições, 2007,

RIBEIRO, Vândiner; PARAÍSO, Marlucy Alves. Currículo e MST: conflitos de saberes e estratégias na produção de sujeitos. Educação \& Realidade, v. 40, n. $03,2015$.

ROCHA, André Carlos de Oliveira; NOBRE, Henderson Gonçalves. Limites e perspectivas da transição agroecológica em assentamentos rurais no nordeste paraense. Retratos de Assentamentos, v. 20, n. 01, 2017.

SOUZA, Daniele Cristina de; VALDANHA NETO; Diógenes. A educação do campo como caminho para a transformação social: notas desde o triângulo mineiro. Cadernos CIMEAC, v. 8, n. 1, 2018.

STAKE, Robert E. Pesquisa qualitativa: estudando como as coisas funcionam. Porto Alegre: Penso, 2011.

WHITAKER, Dulce Consuelo Andreatta. Análise de entrevistas em pesquisas com histórias de vida: questões metodológicas. In: WHITAKER, Dulce Consuelo 
Andreatta; VELÔSO, Thelma Maria Grisi. Oralidades e Subjetividade: os meandros infinitos da memória. Campina Grande: EDUEP, 2005.

WHITAKER, Dulce Consuelo Andreatta. Direitos humanos e reforma agrária. Retratos de Assentamentos, n.14, v.2, 2011.

WHITAKER, Dulce Consuelo Andreatta. Educação Rural: da razão dualista, à razão dialética. Retratos de Assentamentos, n.11, 2008. 